\title{
PENGEMBANGAN SISTEM E-VOTING DENGAN PROTOKOL TWO CENTRAL FACILITIES MENGGUNAKAN FINGERPRINT SEBAGAI OTENTIKASI VOTER
}

\author{
Muhammad Ilyas Sikki, Sugi Guritman and Hendra Rahmawan
}

\author{
Departemen Ilmu Komputer, Fakultas Matematika dan Ilmu Pengetahuan Alam, \\ Institut Pertanian Bogor, Kampus IPB Dramaga 16680 \\ E-mail: muh_ilyas_sikki@yahoo.com
}

\begin{abstract}
The e-voting system which developed using two central facilities protokol consist of three component that is voting machine as client for interaction with voter, central legitimization agency (CLA) as server voter authentication, and central tabulating facility (CTF) as server for result recapitulation voter vote count. Research in this paper just focused to voter authentication process on voting machine toward database of voter that stored in CLA with using fingerprint biometric technology. Fingerprint biometric technology used for voter registration process, voter verification process, and voter authentication process who will doing election. Registration process for acquiring voter fingerprint image database, verification process to be sure voter database can be verificated or not, and authentication process for voter authorization who can be permitted or not by system give of vote in election.
\end{abstract}

Keywords: E-voting, voter, authentication, fingerprint

\begin{abstract}
Abstrak
Sistem e-voting yang dikembangkan menggunakan dua fasilitas pusat Protokol terdiri dari tiga komponen yang suara mesin sebagai klien untuk berinteraksi dengan pemilih, lembaga legitimasi pusat (LLP) sebagai server otentikasi pemilih, dan fasilitas tabulasi pusat (FTP) sebagai server untuk hasil rekapitulasi penghitungan suara pemilih. Penelitian dalam makalah ini hanya difokuskan untuk proses otentikasi pemilih pada mesin voting terhadap database pemilih yang disimpan dalam PKB dengan menggunakan sidik jari teknologi biometrik. Teknologi biometrik sidik jari yang digunakan untuk proses otentikasi proses pendaftaran pemilih, proses verifikasi pemilih, dan pemilih yang akan melakukan pemilihan. Proses pendaftaran untuk mendapatkan pemilih database gambar sidik jari, proses verifikasi untuk memastikan basis data pemilih dapat diverifikasi atau tidak, dan proses otentikasi untuk otorisasi pemilih yang dapat diizinkan atau tidak oleh sistem memberi suara dalam pemilu.
\end{abstract}

Kata kunci: E-voting, pemilih, otentikasi, sidik jari

\section{Pendahuluan}

Pemilihan umum (Pemilu) disebut juga dengan "Political Market" (Dr. Indria Samego), artinya bahwa pemilu adalah pasar politik tempat individu/masyarakat berinteraksi untuk melakukan kontrak sosial (perjanjian masyarakat), antara peserta pemilu (partai politik) dengan pemilih (rakyat) yang memiliki hak pilih setelah terlebih dahulu melakukan serangkaian aktivitas politik yang meliputi kampanye, iklan politik melalui media massa cetak, audio (radio) maupun audio visual (televisi) serta media lainnya seperti spanduk, pamflet, selebaran bahkan komunikasi antar pribadi yang berbentukface to face (tatap muka) atau lobi-lobi yang berisi penyampaian pesan mengenai program, platform, asas, ideologi serta janji-janji politik lainnya, guna meyakinkan pemilih sehingga pada penco- blosan dapat menentukan pilihannya terhadap salah satu partai politik yang menjadi peserta pemilu untuk mewakilinya dalam badan legislatif maupun eksekutif.

Sepanjang sejarah Indonesia, telah diselenggarakan 10 kali pemilu dimana sistem pemilu yang digunakan selama ini adalah cara penyoblosan atau penyontrengan. Cara konvensional seperti ini ternyata dapat menimbulkan masalah seperti pemilih ganda, penggelembungan suara dan kesalahan lainnya serta lamanya waktu rakapitulasi suara. Untuk mengatasi hal tersebut, solusi yang dapat dilakukan adalah pengembangan electronic voting (e-voting) melalui sistem pemilu secara online yang dibangun menggunakan suatu protokol yang aman dan memenuhi standar secure voting requirements menurut paparan [1]. Protokol yang dapat memenuhi sebagian standar kriteria secure voting requirements 
108 Journal of Information Systems, Volume 9, Issue 2, October 2013

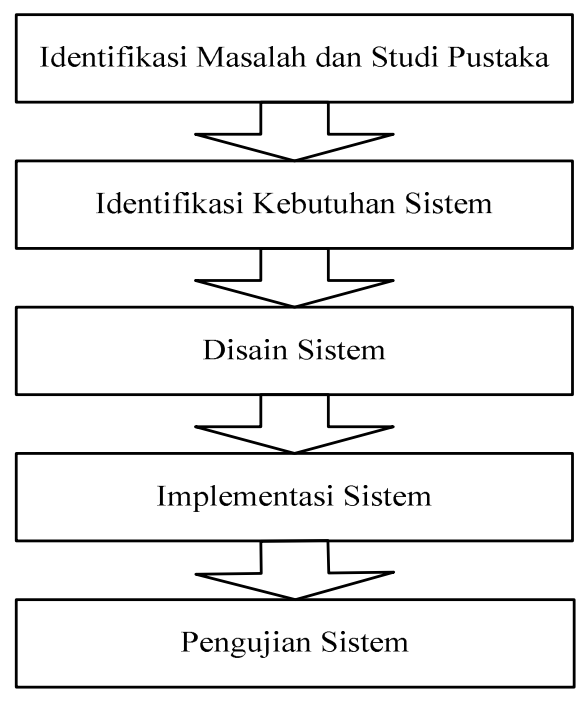

Gambar 1. Alur Proses Penelitian

adalah Two Central Facilities Protocol, dimana terdiri dari Central Legitimazation Agency (CLA) untuk pengesahan pemilih dan Central Tabulating Facility (CTF) untuk perhitungan suara [1].

Penelitian [2] telah memberikan pemaparan tentang sistem pemilu online. Dalam pemaparan tersebut menjelaskan persyaratan untuk desain protokol dan asumsi-asumsi dalam implementasi pemilu secara online, komponen-komponen yang terkait, fungsi dari CLA dan CTF serta mendeskripsikan protokol proses interaksi antara CLA dan CTF. [3] mengembangkan protokol keamanan pemilihan untuk secure online voting dengan menggunakan protokol Two Central Facilities yang mengimplementasikan pengembangan CLA dan CTF untuk menghasilkan pemilu virtual yang aman dengan mengkombinasikan kunci publik/simetrik dan fungsi hashing.

Penelitian yang dilakukan oleh [4] mencoba mengembangkan sistem online voting pada IPB dengan berbasis protokol Two Central Facilities (CTF) yang hanya memanfaatkan jaringan sebatas cakupan satu departemen di IPB, dan penelitian yang dilakukan oleh [5] dengan pengembangan disain e-voting pilkada Kota Bogor menggunakan protokol Two Central Facilities, dimana sistem otentikasi pada Voter menggunakan media smart card, tetapi jika diimplementasikan masih memiliki kelemahan misalnya pemilih yang datang saat pemungutan suara memungkinkan bukan pemilik kartu yang sah. Oleh karena itu dikembangkan dengan menggunakan sidik jari untuk otentikasi pemilih.

Penelitian ini bertujuan untuk pengembangan protokol keamanan sistem otentikasi voter pada CLA dengan protokol Two Central Facilities dan otentikasi voter pada mesin voting menggunakan

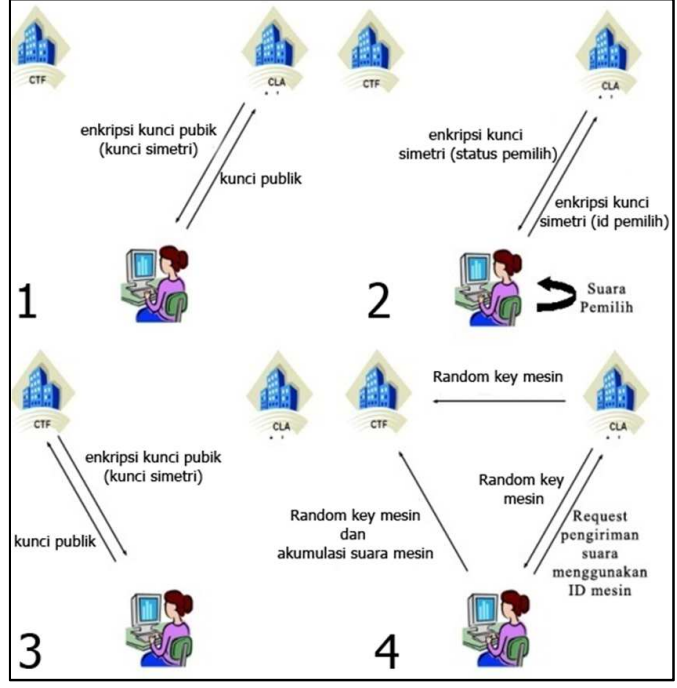

Gambar 2. Skema e-voting Two Central Facilities

fingerprint untuk implementasi sistem pemilu yang diselenggarakan secara online.

\section{Metodologi}

Metode penelitian yang digunakan adalah model alur proses yang dapat diperlihatkan pada Gambar 1.

\section{Hasil dan Pembahasan}

\section{Identifikasi Masalah dan Studi Pustaka}

Identifikasi masalah dilakukan dengan cara mencari informasi baik secara langsung melalui diskusi dan wawancara dengan pihak KPU maupun secara tidak langsung melalui media massa. Dengan banyaknya permasalahan yang timbul, maka gagasan untuk melaksanakan pemilihan umum dengan memanfaatkan perkembangan teknologi yang ada khususnya teknologi elektronik dan berbasis web (online voting) diperlukan. Penelitian yang telah dilakukan oleh [5] mencoba mengembangkan sistem $e$-voting (online voting) untuk memberikan alternatif solusi pemecahan atas permasalahn-permasalan yang mungkin timbul dalam penyelenggaraan pemilu secara konvensional di Indonesia selama ini. Dalam penelitiannya, mengembangkan protokol e-voting Two Central Facilities untuk proses otentikasi pemilih menggunakan mifare card reader (smart card) sebagai media Personal Identity (ID) bagi pemilih yang akan melakukan proses pemberian suara pada penyelenggaraan pemilu. Skema $e$-voting yang dikembangkan [5] dapat dilihat pada Gambar 2.

Hasil dari penelitian [5] ini jika diterapkan masih memungkinkan adanya kecurangan atau per- 
masalahan dilapangan pada saat pelaksanaan pemilihan (pemungutan suara). Permasalan-permasalahan yang mungkin timbul tersebut adalah: 1) $\mathrm{Ku}-$ rang terjaminnya keabsahan pemilih yang akan memberikan suara; 2) Pemilih yang akan memberikan suaranya masih memungkinkan berpura-pura menjadi pemilih yang lain; 3) Pemilih yang tidak sah dan belum memenuhi persyaratan sebagai warga negara yang memiliki hak untuk memilih masih memungkinkan memberikan suaranya; 4) Pemilih yang berhak memilih masih memungkinkan menitipkan kartunya atau mewakilkan kepada orang lain untuk memberikan suaranya.

Dengan permasalahan-permasalahan tersebut di atas, dapat dieliminir dengan pemanfaatan sidik jari sebagai otentikasi pemilih saat pemungutan suara.

\section{Identifikasi Kebutuhan Sistem}

Kebutuhan sistem untuk proses otentikasi pemilih menggunakan mesin fingerprint scanner, dimana proses otentikasi ini berlangsung pada komunikasi antara mesin voting dengan server CLA sehingga pemilih yang bersangkutan yang harus memberikan suaranya dan tidak memungkinkan akan diwakilkan atau digantikan dengan orang lain dalam proses pemingutan suara.

Hal yang perlu juga diperhatikan dalam pengembangan sistem $e$-voting adalah spesifikasi dari kebutuhan sistem. Secara umum sistem otentikasi voter yang dibangun dapat memenuhi spesifikasi sebagai berikut : 1) sistem mampu memfasilitasi

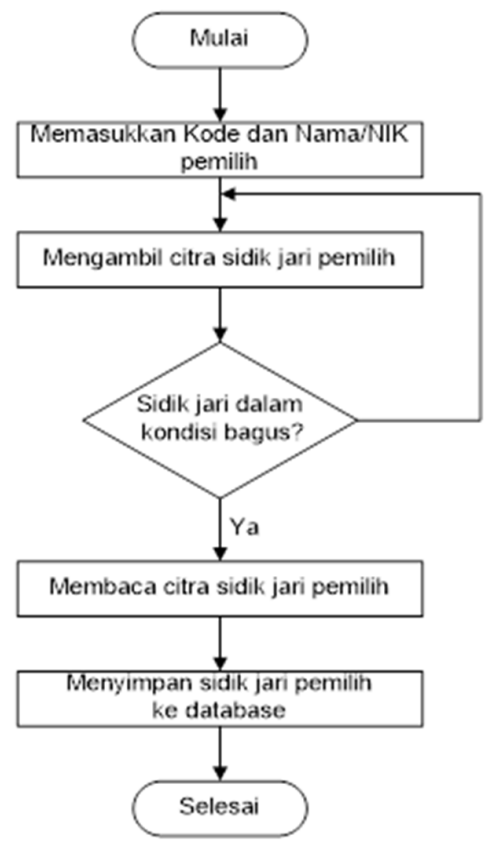

Gambar 4. Diagram alir proses registrasi pemilih proses pemilu yang disesuaikan dengan kondisi di indonesia; 2) sistem mampu melakukan verifikasi data pemilih (voter) dan mencatat status pemilih apakah telah melakukan proses pemungutan suara atau belum; 3) hanya sidik jari pemilih yang terdaftar pada sistem yang diizinkan melakukan pemilihan; 4) pemilih dapat memasukkan pilihannya ke dalam sistem, dimana seorang pemilih hanya berhak melakukan pemungutan suara sebanyak satu kali; 5) setiap pemilih yang telah melakukan pemilihan tidak dapat melakukan pemilihan lagi; 6) tidak boleh memberikan lebih dari satu kali suara; 7) tidak ada yang bisa mengubah pilihan orang lain; 8) setiap pemilih dapat memastikan bahwa suara mereka sudah dikirimkan dan terhitung dalam penghitungan akhir.

\section{Desain Sistem}

Perancangan yang dikembangkan dari sistem $e$-voting ini dengan protokol two central facilities menggunakan fingerprint (sidik jari) meliputi proses registrasi database pemilih dan proses otentikasi pemilih. Diagram alir proses registrasi database sidik jari pemilih dapat dilihat pada Gambar 3. Pada proses ini, data masukan sidik jari yang didapat dari hasil akuisisi oleh mesin sensor sidik jari, akan melalui tahapan verifikasi yang selanjut-

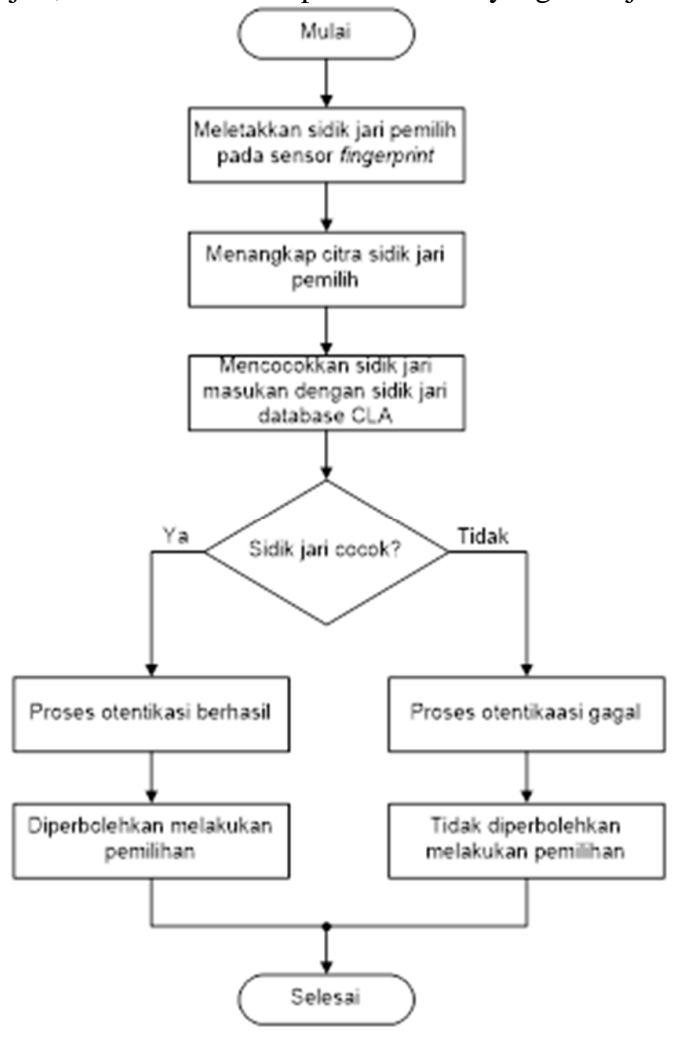

Gambar 3. Diagram alir proses otentikasi pemilih 


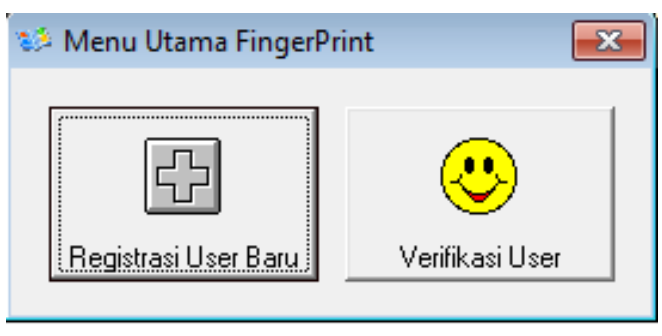

Gambar 5. Menu utama fingerprint

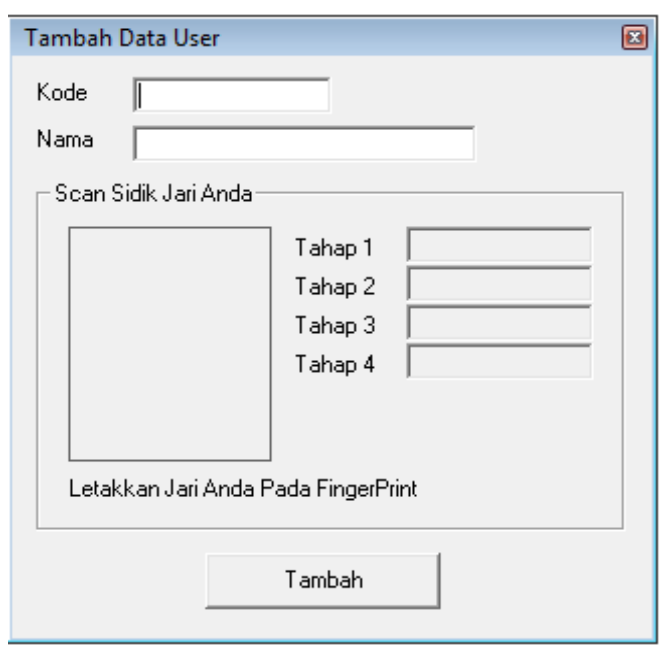

Gambar 7. Menu registrasi pemilih

nya saat data telah dikenali dilanjutkan meregistrasi data tersebut ke database.

Proses otentikasi pemilih merupakan proses membandingkan sidik jari yang dicocokkan satusatu dimana setiap sidik jari masukan dibandingkan dengan satu template sidik jari tertentu yang tersimpan dalam database pada server CLA. Keluaran dari program ini adalah keputusan apakah proses otentikasi pemilih berhasil atau gagal. Jika proses otentikasi berhasil maka pemilih akan langsung diarahkan ke halaman kotak suara untuk memilih kandidat yang diinginkan. Diagram alir proses otentikasi pemilih dapat dilihat pada Gambar 4.

\section{Implementasi Sistem}

Aplikasi yang digunakan dalam implementasi sistem untuk proses registrasi dan proses otentikasi pemilih yang mendukung mesin fingerprint scanner menggunakan bahasa pemograman visual basic 6.0 (VB6).

\section{Proses Registrasi Pemilih}

Proses registrasi ini diakukan dengan pengambilan citra sidik jari dari pemilih yang telah memenuhi persyaratan untuk berhak memilih dalam pemilu

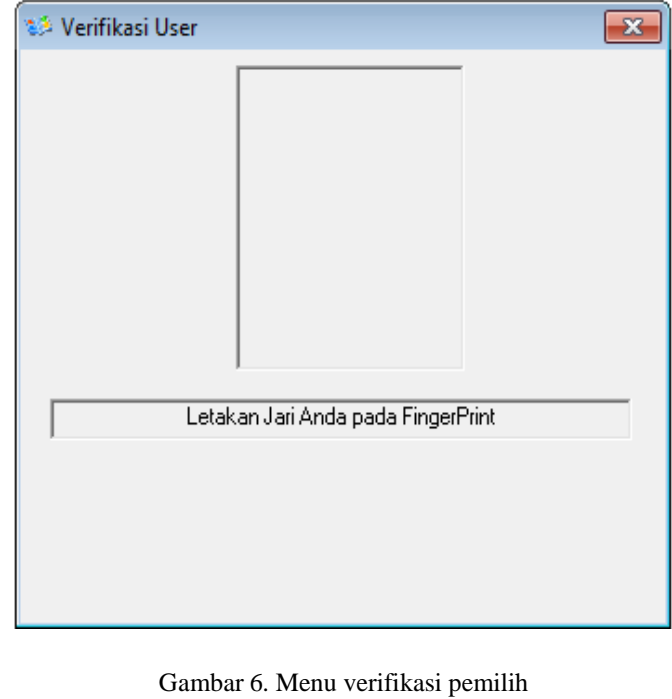

sesuai dengan undang-undang yang berlaku. Pengambilan citra sidik jari dilakukan dengan menempelkan sidik jari pada sensor mesin fingerprint scanner $\mathrm{U}$ are. U4500. Menu utama fingerprint untuk proses awal ke menu registrasi pemilih dan verifikasi data citra sidik jari pemilih yang telah diambil diperlihatkan pada Gambar 5. Sedangkan Gambar 6 dan Gambar 7 memperlihatkan menu registrasi pemilih untuk proses pengambilan citra sidik jari pemilih yang akan disimpan ke database dan menu verifikasi pemilih untuk proses verifikasi pemilih yang telah diambil (direkam) citra sidik jarinya sebagai pengaktifan sidik jari pemilih agar dapat digunakan dalam proses otentikasi saat akan dilakukan pemilihan.

Pada proses registrasi sidik jari pemilih, sebelum pengambilan citra sidik jari pemilih diawali dengan memasukkan Kode dan Nama/NIK pemilih sebagai identitas pemilih. Terdapat 4 tahap proses pengambilan citra sidik jari dimana setiap tahap mesin fingerprint scanner membaca sidik jari pemilih, secara otomatis aplikasi dari mesin akan mengaktifkan sensor pembaca. Setelah data berhasil didapat maka sensor pembaca dari mesin fingerprint scanner $\mathrm{U}$ are.U4500 akan tidak aktif lagi, data yang diperoleh pada ke empat tahap pembacaan tersebut akan dicocokkan satu sama lain dan hasil akuisisi data dalam kondisi bagus, tahap selanjutnya akan disimpan kedalam database. Proses pengambilan registrasi citra sidik jari pemilih ditunjukkan pada Gambar 8.

Gambar 9 memperlihatkan proses verifikasi data sidik jari pemilih yang telah diambil (terekam ke dalam database) untuk memastikan apakah sidik jari tersebut dapat diaktifkan dan digunakan dalam proses otentikasi pemilih pada proses pemilihan. Sedangkan Gambar 10 memperlihatkan bahwa 


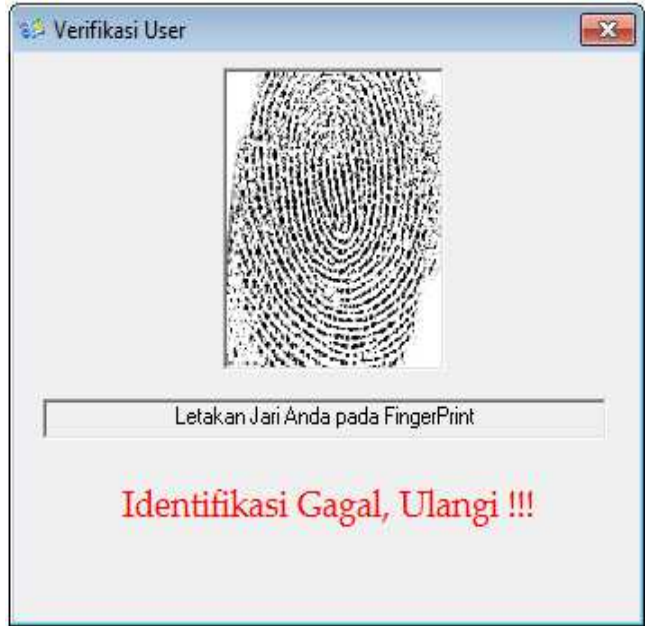

Gambar 9. Proses verifikasi gagal

proses verifikasi pemilih yang gagal karena data sidik jari pemilih yang bersangkutan tidak terdaftar.

\section{Proses Otentikasi Pemilih}

Proses otentikasi ini dilakukan sebagai langkah awal sebelum pemilih yang memenuhi peryaratan dan berhak melakukan pemilihan suara diperkenankan memberikan pilihannya. Pada proses ini juga dilakukan untuk memastikan bahwa hanya pemilih yang sudah terdaftar pada database sistem yang diperbolehkan memberikan suaranya. Halaman antarmuka untuk login proses otentikasi pemilih dapat ditunjukkan pada Gambar 11. Setiap pemilih agar dapat masuk ke halaman surat suara pada sistem evoting untuk memberikan pilihannya terlebih dahulu harus melakukan login pada menu halaman voting client sebagaimana diperlihatkan pada Gambar 11. Tahap awal untuk proses otentikasi pemilih dimana pemilih yang akan melakukan pemilihan meletakkan sidik jarinya pada sensor mesin fingerprint yang sudah terkoneksi dengan mesin voting yang digunakan.

Setelah pemilih menempelkan sidik jarinya pada mesin fingerprint scanner, maka aplikasi dari mesin fingerprint scanner akan mengaktifkan sensor secara otomatis untuk membaca dan menangkap citra sidik jari pemilih yang bersangkutan. Selanjutnya citra sidik jari tersebut sebagai masukan oleh sistem yang akan dicocokkan dengan sidik jari pada database yang telah diambil dan disimpan saat proses registrasi pemilih untuk proses otentikasi pemilih. Proses selanjutnya, sistem melakukan proses otentikasi pemilih dan apabila sidik jari pemilih dikenal oleh sistem maka sistem akan membuka halaman surat suara sehingga pemilih diperbolehkan melakukan pemilihan. Sebaliknya, apabi-

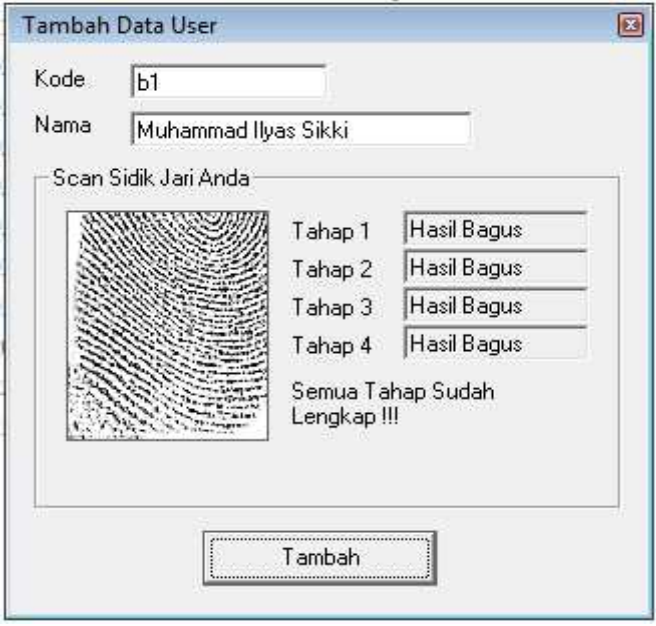

Gambar 8. Proses registrasi sidik jari pemilih

la sistem tidak mengenal sidik jari yang sedang diotentikasi maka sistem tidak membuka halaman surat suara sehingga pemilih tidak bisa melakukan pemilihan. Proses otentikasi terhadap sidik jari pemilih yang dikenal dan tidak dikenal oleh sistem ditunjukkan pada Gambar 12 dan Gambar 13.

\section{Pengujian Sistem}

Pengujian terhadap sistem $e$-voting ini yang difokuskan pada pemanfaatan sidik jari untuk otentikasi pemilih dalam pemilu dilakukan menggunakan blackbox testing. Pengujian yang dilakukan meliputi tahapan sebagai berikut :

\section{Tahap Pengujian Pada Proses Registrasi}

Tahap pengujian pada proses registrasi pemilih dengan menggunakan mesin fingerprint scanner yang sebelumnya telah dikonfigurasikan dengan sistem yang dikembangkan oleh Fitrah, dkk (2012) untuk memperoleh citra databese sidik jari dari pemilih yang akan melakukan pemilihan. Pada tahap ini akan dilihat apakah sensor dari mesin fingerprint scanner yang digunakan dapat mengakuisisi sidik jari pemilih yang diregister dengan kondisi bagus melalui empat tahap mengambilan. Pada tahap ini juga akan dilihat apakah sistem dapat menyimpan identitas pemilih yang berupa Kode dan Nama/NIK yang dimasukkan saat registrasi pemilih untuk pengambilan data sidik jari.

Tahap Pengujian Pada Proses Verifikasi Pemilih Tahap pengujian pada proses verifikasi pemilih untuk menguji apakah sistem dapat menangkap dan membaca citra sidik jari pemilih yang akan melakukan pemilihan melalui sensor dari mesin fingerprint scanner yang digunakan. Pada tahap ini akan dilihat sistem akan menampilkan Nama/NIK dari 


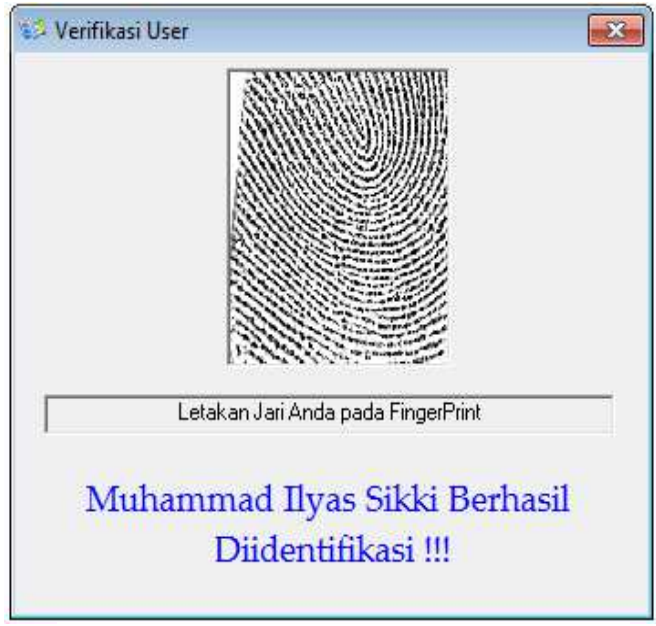

Gambar 11. Proses verifikasi berhasil

pemilih yang dapat diverifikasi sesuai dengan Nama/NIK yang tersimpan dari database sidik jari pemilih yang bersangkutan. Pada tahap ini juga akan dilihat apakah sistem gagal menvrifikasi pemilih yang tidak sesuai dengan database sidik jari pemilih atau sidik jari pemilih yang tidak terdaftar.

Tahap Pengujian Pada Proses Otentikasi Pemilih Tahap pengujian pada proses otentikasi pemilih dimana saat pemilih akan melakukan pemilihan melalui sistem $e$-voting yang dikembangkan untuk memberikan suaranya. Pada tahap ini dilakukan pengujian terhadap sistem untuk menunjukkan apakan sistem dapat bekerja dengan baik sesuai performa sistem yang diharapkan untuk melakukan

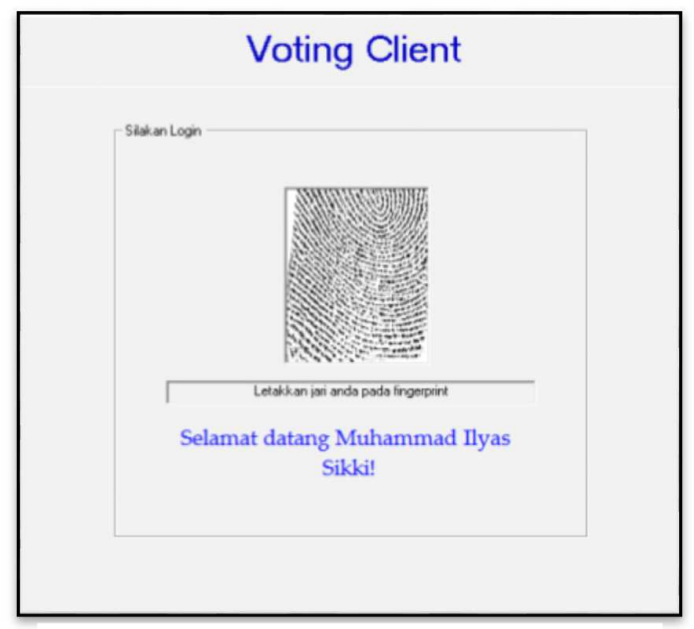

Gambar 10. Proses otentikasi berhasil

otentikasi kepada pemilih yang akan menggunakan hak pilihnya dalam pemilu. Dalam pengujian ini, sistem dapat memperlihatkan bahwa otentikasi bisa dilakukan terhadap pemilih yang sudah terdaftar sidik jarinya dalam database pemilih, sehingga pemilih yang terotentikasi dapat diperbolehkan untuk memberikan suaranya oleh sistem dengan diarahkannya pemilih ke halaman surat suara. Dalam pengujian ini pula sistem dapat memperlihatkan bahwa pemilih yang sidik jarinya tidak terdaftar dalam database pemilih, maka sistem tidak mengenal sidik jari pemilih tersebut sehingga tidak dapat melakukan pemilihan karena sistem tidak mengarahkan pemilih ke halaman surat suara...

TABEL 1

HASIL PENGUJian

\begin{tabular}{|c|c|c|c|c|c|}
\hline No. & Deskripsi Uji & Kondisi Awal & Skenario Uji & Hasil yang diharapkan & Hasil Uji \\
\hline 1. & $\begin{array}{l}\text { Mengambil citra sidik jari pe- } \\
\text { milih, memasukkan Kode dan } \\
\text { Nama/NIK dari pemilih me- } \\
\text { nggunakan mesin fingerprint } \\
\text { scanner }\end{array}$ & $\begin{array}{l}\text { Jari pemilih belum di- } \\
\text { letakan pada sensor } \\
\text { dari mesin fingerprint } \\
\text { scanner yang diguna- } \\
\text { kan }\end{array}$ & $\begin{array}{l}\text { Pemilih meletak- } \\
\text { kan jarinya pada } \\
\text { sensor mesin fing- } \\
\text { erprint scanner }\end{array}$ & $\begin{array}{l}\text { Sistem merekam dan me- } \\
\text { nyimpan citra sidik jari } \\
\text { pemilih, Kode dan Nama/ } \\
\text { NIK ke dalam database }\end{array}$ & Berhasil \\
\hline 2. & $\begin{array}{l}\text { Menangkap dan membaca ci- } \\
\text { tra sidik jari dari pemilih yang } \\
\text { telah terdaftar dalam database }\end{array}$ & $\begin{array}{l}\text { Jari pemilih belum di- } \\
\text { letakan pada sensor } \\
\text { dari mesin fingerprint } \\
\text { scanner yang diguna- } \\
\text { kan }\end{array}$ & $\begin{array}{l}\text { Pemilih meletak- } \\
\text { kan jarinya pada } \\
\text { sensor mesin fing- } \\
\text { erprint scanner }\end{array}$ & $\begin{array}{l}\text { Sistem mencocokkan ci- } \\
\text { tra sidik jari pemilih de- } \\
\text { ngan database yang ada } \\
\text { untuk diverifikasi }\end{array}$ & Berhasil \\
\hline 3. & $\begin{array}{l}\text { Menangkap dan membaca ci- } \\
\text { tra sidik jari dari pemilih yang } \\
\text { tidak terdaftar dalam databa- } \\
\text { se }\end{array}$ & $\begin{array}{l}\text { Jari pemilih belum di- } \\
\text { letakan pada sensor } \\
\text { dari mesin fingerprint } \\
\text { scanner yang diguna- } \\
\text { kan }\end{array}$ & $\begin{array}{l}\text { Pemilih meletak- } \\
\text { kan jarinya pada } \\
\text { sensor mesin fing- } \\
\text { erprint scanner }\end{array}$ & $\begin{array}{l}\text { Sistem mencocokkan ci- } \\
\text { tra sidik jari pemilih de- } \\
\text { ngan database yang ada } \\
\text { untuk diverifikasi }\end{array}$ & $\begin{array}{l}\text { Berhasil } \\
\text { sidik jari } \\
\text { gagal } \\
\text { diverifi } \\
\text { kasi }\end{array}$ \\
\hline 4. & $\begin{array}{l}\text { Menangkap dan membaca ci- } \\
\text { tra sidik jari dari pemilih yang } \\
\text { telah terdaftar dalam database } \\
\text { yang akan melakukan pemili- } \\
\text { han }\end{array}$ & $\begin{array}{l}\text { Jari pemilih belum di- } \\
\text { letakan pada sensor } \\
\text { dari mesin fingerprint } \\
\text { scanner yang diguna- } \\
\text { kan }\end{array}$ & $\begin{array}{l}\text { Pemilih meletak- } \\
\text { kan jarinya pada } \\
\text { sensor mesin fing- } \\
\text { erprint scanner }\end{array}$ & $\begin{array}{l}\text { Sistem mencocokkan ci- } \\
\text { tra sidik jari pemilih de- } \\
\text { ngan database yang ada } \\
\text { untuk diotentikasi }\end{array}$ & Berhasil \\
\hline 5. & $\begin{array}{l}\text { Menangkap dan membaca ci- } \\
\text { tra sidik jari dari pemilih yang } \\
\text { tidak terdaftar dalam databa- } \\
\text { se yang akan melakukan pe- } \\
\text { milihan }\end{array}$ & $\begin{array}{l}\text { Jari pemilih belum di- } \\
\text { letakan pada sensor } \\
\text { dari mesin fingerprint } \\
\text { scanner yang diguna- } \\
\text { kan }\end{array}$ & $\begin{array}{l}\text { Pemilih meletak- } \\
\text { kan jarinya pada } \\
\text { sensor mesin fing- } \\
\text { erprint scanner }\end{array}$ & $\begin{array}{l}\text { Sistem mencocokkan ci- } \\
\text { tra sidik jari pemilih de- } \\
\text { ngan database yang ada } \\
\text { untuk diotentikasi }\end{array}$ & $\begin{array}{l}\text { Berhasil } \\
\text { sidik jari } \\
\text { tidak } \\
\text { dikenal }\end{array}$ \\
\hline
\end{tabular}




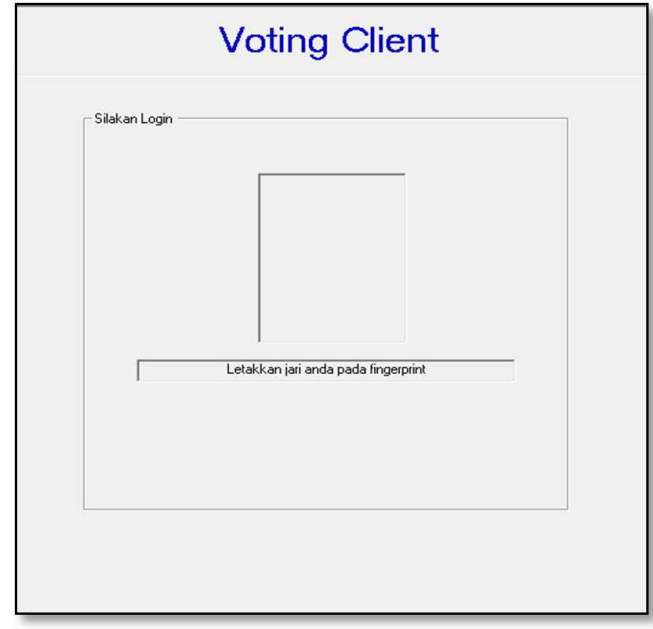

Gambar 13. Menu login

Hasil pengujian terhadap tahapan proses re-gistrasi pemilih, proses verifikasi pemilih, dan pro-ses otentikasi pemilih tersebut di atas dapat diperlihatkan pada Tabel 1

\section{Kesimpulan}

Pengembangan sistem $e$-voting dengan protokol two central facilities yang telah ada dapat dikembangkan dan disesuaikan dengan sistem implementasikan penyelenggaraan pemilihan di wilayah Indonesia dan juga dapat memenuhi spesifikasi persyaratan dari secure voting. Sistem $e$-voting yang dikembangkan ini merupakan prototype yang apabila akan diimplementasikan untuk menggantikan sistem penyelenggaraan pemilihan secara konvensional (paper based) dapat mengeliminir permasalahan-permasalahan yang mungkin timbul dalam pelaksanaan pemungutan suara selama ini dengan adanya pemanfaatan teknologi biometric untuk verifikasi dan otentikasi pemilih. Penggunakan sidik jari untuk proses otentikasi pemilih yang akan melakukan proses pemilihan dalam penyelengaraan pemilu akan memastikan bahwa pemilih yang bersangkutan yang diperbolehkan memberikan suaranya tanpa bisa diwakili atau ditipkan ke orang lain sehingga dapat membantu meningkatkan keabsahan dari pemungutan suara yang dilakukan.

Pada penelitian ini sistem yang dikembangkan belum sempurna masih memiliki kelemahan dan kekurangan sehingga diharapkan dapat terus dikembangkan dan diperbaiki pada penelitian selanjutnya. Beberapa rekomendasi saran yang bisa dijadikan acuan untuk penelitian ke depan diantaranya adalah: 1) penggunaan teknologi biometric retina mata untuk proses otentikasi pemilih dalam pemungutan suara pada penyelenggaraan pemilu. ataupun dapat juga digunakan kedua teknologi bio-

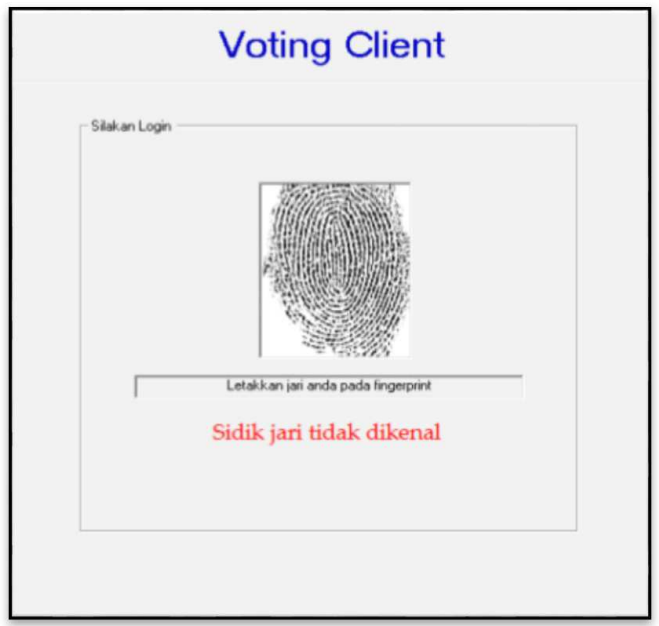

Gambar 12. Proses otentikasi gagal

metric sidik jari dan retina mata dalam proses otentikasi pemilih untuk meningkatkan protokol keamanan terhadap pemilih yang akan memberikan suaranya; 2) dilakukan penelitian lebih mendalam pengembangan dan penerapan sistem $e$-voting ini yang dapat ditinjau dari aspek ekonomi, sosial, hukum, dan politik untuk mendukung reliabilitas sistem jika akan diimplementasikan; 3) diperlukan pengembangan protokol pemilu yang didisain sendiri dan diuji disesuaikan dengan undang-undang tentang pemilu dan tahapan-tahapan proses pelaksanaan pemilu sehingga memudahkan apabila akan diimplementasikan di lapangan.

\section{Referensi}

[1] Schneier B. 1996. Applied Cryptography, second edition: Protocols, Algorithms, and Source Code in C, John Wiley \& Sons, Inc.

[2] DuFeu D, Harris J. 2001. Online Election System, 95.413 Project Report, Carleton University.

[3] Sireesha J, Chakchai SI. 2005. Secure Virtual Election Both with Two Central Facilities, Department of Komputer Science Washington University in St. Louis, USA.

[4] Wardhani, dkk. 2009. Analisis dan Pengembangan IPB Online Voting Berbasis Protokol Two Central Facilities, Fakultas Matematika dan Ilmu Pengetahuan Alam, Institut Pertanian Bogor, Bogor.

[5] Fitrah, dkk. (2012), Disain Evoting pada Pilkada Kota Bogor Menggunakan Protokol two Central Facilities yang Termodifikasi, Fakultas Matematika dan Ilmu Pengetahuan Alam, Institut Pertanian Bogor, Bogor.

[6] D. Ashok K, T, Ummal SB. 2011. A Novel Design of Electronic Voting System Using 
114 Journal of Information Systems, Volume 9, Issue 2, October 2013

Fingerprint, Department of Computer Science, V.S.S. Government Art College, India.

[7] Iqbal, Sigit. Implementasi dan Analisis Performansi Autentikasi Sistem Biometrik Sidik Jari, Departemen Teknik Telemomunikasi, ITB Bandung.
[8] Shalahuddin, Muhammad.2009. Pembuatan Model E-Voting Berbasis Web. Studi Kasus Pemilu Legislatif dan Preside Indonesia. Sekolah Teknik Elektro dan Informatik, Institut Teknologi Bandung, Bandung. 